\title{
Analisis Perbandingan Material Slab Beton Pada Perkerasan Apron dengan Menggunakan Program Bantu Elemen Hingga
}

\author{
Hendrawan Setyo Warsito, Ervina Ahyudanari dan Januari Jaya Ekaputri \\ Jurusan Teknik Sipil, Fakultas Teknik Sipil dan Perencanaan, Institut Teknologi Sepuluh Nopember (ITS) \\ Jl. Arief Rahman Hakim, Surabaya 60111 Indonesia \\ e-mail: ervina@ce.its.ac.id, januarti@ce.its.ac.id
}

\begin{abstract}
Abstrak - Kekuatan slab beton sangat dipengaruhi oleh jenis material yang dipakai. Jenis material yang dimaksud adalah material beton dengan menggunakan PC (Portland Cement) dan penggunaan geopolimer dalam komposisi campuran slab beton. Beton geopolimer merupakan beton yang ramah lingkungan.

Permasalahan lain yang timbul adalah letak roda pesawat tidak selalu berada pada titik yang sama disuatu permukaan slab beton apron. Pada tugas akhir ini dimaksudkan untuk menganalisis suatu slab beton yang dibebani roda pesawat dengan campuran variasi material beton dan variasi letak roda pesawat pada slab beton dengan program bantu metode elemen hingga.

Dengan data pergerakan pesawat, spesifikasi apron bandara Juanda kondisi eksisting. Dilakukan perhitungan tebal slab beton menggunakan software FAARFIELD dan diperoleh tebal slab beton sebesar $442,5 \mathrm{~mm}$.

Dari analisis program bantu elemen hingga dapat diperoleh tegangan pada slab beton yang ditimbulkan oleh pembebanan roda pesawat. Hasil validasi dari analisis tegangan menggunakan program bantu elemen hingga dengan analisis Westergaard yaitu memiliki nilai tegangan yang hampir sama pada ketebalan slab beton $450 \mathrm{~mm}$.

Nilai tegangan tiap-tiap material beton menunjukan nilai tebal slab beton yang diijinkan untuk tipe pesawat tertentu. Dari analisis menggunakan program bantu elemen hingga tebal slab beton yang diijinkan untuk material slab beton PC yaitu sebesar $425 \mathrm{~mm}$. Sedangkan untuk material beton geopolimer yaitu sebesar $415 \mathrm{~mm}$.
\end{abstract}

Kata Kunci - Apron, Beton Geopolimer, Perkerasan Kaku, Program Bantu Elemen Hingga, Slab Beton, Westergaard.

\section{PENDAHULUAN}

\section{A. Latar Belakang}

PERKERASAN kaku pada apron bandara didesain menggunakan beban statis. Slab beton merupakan komponen utama pada struktur perkerasan kaku apron untuk memikul beban pesawat. Pada tugas akhir ini dimaksudkan untuk menganalisis suatu slab beton yang dibebani roda pesawat[1] dengan material beton PC (Portland Cement) dan variasi campuran material beton yang berbeda. Variasi campuran material yang dimaksud adalah penggunaan geopolimer dalam komposisi campuran slab beton. Beton geopolimer sendiri adalah jenis beton yang $100 \%$ tidak menggunakan semen dan beton geopolimer sendiri merupakan beton yang ramah lingkungan.
Simulasi variasi beban pesawat dan karakteristik material beton dimaksudkan untuk mengetahui efek beban dilapangan terhadap tegangan-tengangan yang terjadi pada slab beton. Dari simulasi diharapkan hasil yang dapat memberikan gambaran yang lengkap dari suatu uji material beton baru yang dilakukan di laboraturium. Dengan diketahuinya perilaku slab beton dari berbagai bahan campuran slab beton, nantinya dapat direkomendasikan campuran material slab beton yang sesuai untuk memfasilitasi pergerakan pesawat.

B. Perumusan Masalah

Berdasarkan pada latar belakang yang telah diuraikan di atas, maka terdapat beberapa permasalahan yang akan dibahas dalam Tugas Akhir ini, antara lain:

1. Bagaimana menentukan tebal slab beton pada perkerasan kaku di apron dengan menggunakan program FAARFIELD?

2. Bagaimana memodelkan perkerasan slab beton untuk apron pada program bantu elemen hingga?

3. Bagaimana pengaruh variasi letak roda pendaratan pesawat terhadap tegangan yang terjadi pada perkerasan slab beton PC (Portland Cement)?

4. Bagaimana pengaruh variasi material beton terhadap daya dukung perkerasan slab beton pada apron?

5. Berapa lama slab beton pada perkerasan kaku dapat memberikan layanan di apron?

\section{Tujuan}

Dari permasalahan yang ada diatas, adapun tujuan yang ingin dicapai dalam penyusunan tugas akhir adalah :

1. Mengetahui tebal slab beton yang dihasilkan dengan menggunakan program FAARFIELD

2. Mengetahui cara memodelkan perkerasan slab beton untuk apron pada program bantu elemen hingga.

3. Menganalisis pengaruh variasi letak roda pendaratan pesawat pada slab beton terhadap tegangan yang terjadi pada perkerasan slab beton PC (Portland Cement).

4. Menganalisis pengaruh variasi material geopolimer terhadap daya dukung slab beton pada apron.

5. Mengetahui jangka waktu ketahanan slab beton terhadap daya dukung memberikan layanan pada apron.

\section{Batasan dan Ruang Lingkup}

Dalam penulisan tugas akhir ini terdapat batasan masalah agar materi yang dibahas didalamnya tidak menyimpang dan tetap fokus. Batasan masalah tersebut antara lain : 
1. Untuk pembebanan digunakan tipe pesawat hasil perhitungan beban terbesar dari masing-masing roda pesawat.

2. Faktor cuaca tidak diperhitungkan.

3. Ejek jet blast tidak diperhitungkan.

4. Jenis campuran material beton geopolimer telah ditentukan dan diuji di laboraturium.

5. Daya dukung perkerasan tanah dasar (nilai k) ditentukan pada Bandara Juanda dengan Nilai k yang sesuai dengan nilai PCN apron, yaitu pada terminal $1: 98 / \mathrm{R} / \mathrm{C} / \mathrm{X} / \mathrm{T}$ sedangkan pada terminal 2 : 77/R/C/X/T. Dengan kode C maka nilai "k" dapat diperoleh $25-60 \mathrm{MN} / \mathrm{m}^{3}$

\section{URAIAN PENELITIAN}

Metodologi yang digunakan dalam studi ini dimulai dengan pengumpulan data pergerakan pesawat dan data kekuatan tanah dasar. Data yang diperoleh digunakan untuk membuat permodelan dengan program bantu elemen hingga. Hasil dari permodelan tersebut digunakan untuk mengetahui pengaruh jenis material terhadap kekuatan beton yang dibebani roda pesawat.

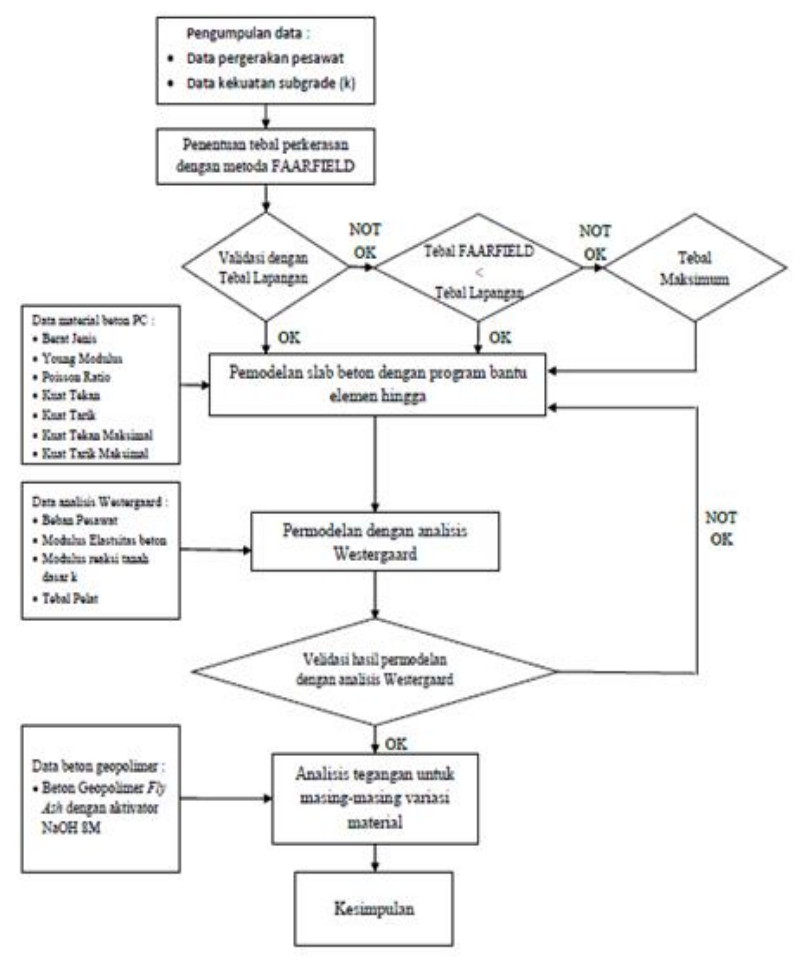

Gambar 1-Diagram Alir Analisis Data

\section{HASIL DAN PEMBAHASAN}

\section{A. Umum}

Dalam bab ini dilakukan analisis terhadap data yang ada untuk mendapatkan nilai tegagan dari perkerasan pada apron sesuai dengan tujuan dari tugas akhir ini. Nilai tegangan diperoleh dari mensimulasikan letak beban pada suatu slab beton. Simulasi dari tugas akhir ini digunakan program bantu dengan metode elemen hingga. Hasil dari simulasi dengan program bantu elemen hingga akan divalidasi dengan perhitungan tegangan metode Westergaard. Adapun langkah pertama sebelum permodelan adalah penentuan tebal perkerasan. Tebal perkerasan diperoleh dengan perhitungan menggunakan program bantu FAARFIELD [2]\&[3]. Dan hasil dari perhitungan FAARFIELD akan dikomparasikan dengna tebal perkerasan di lapangan. Hasil komparasi akan menjadi acuan dalam membuat model perkerasan slab beton dengan program bantu elemen hingga.

\section{B. Analisis Tebal Perkerasan Menggunakan} FAARFIELD

Pada studi kasus ini dilakukan analisis penentuan tebal slab menggunakan software Dari software FAARFIELD. Data yang digunakan adalah data pergerakan pesawat di Juanda pada tahun 2014 dan kondisi eksisting apron bandara Juanda. Dari hasil analisis FAARFIELD dihasilkan tebal pelat beton sebesar 442,5 mm. Berdasarkan data yang ada yaitu tebal perkerasan slab beton pada lapangan yakni $450 \mathrm{~mm}$. Sehingga dalam menganalisis tegangan pelat beton PC digunakan tebal lapangan yakni sebesar $450 \mathrm{~mm}$.

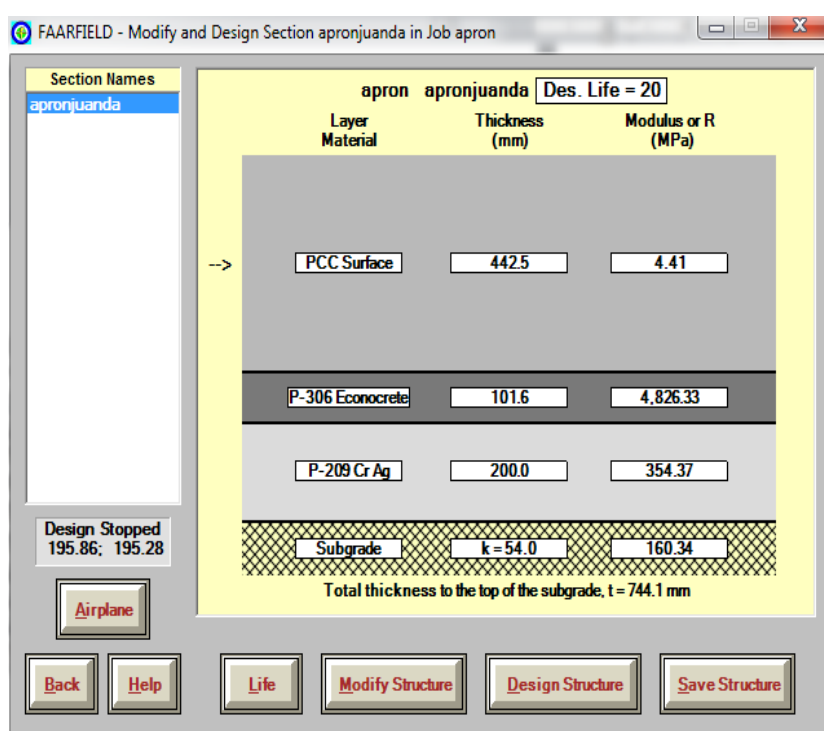

Gambar 2-Hasil Analisis Menggunakan FAARFIELD

C. Analisis Tegangan Slab Beton menggunakan program bantu elemen hingga dan divalidasi dengan metode Westergaard

Jenis material yang digunakan pada tahap analisis ini adalah material beton PC dengan karateristik yang sama dengan material beton PC pada bandara Juanda, Surabaya. Untuk karateristik beton PC yang digunakan dalam program bantu elemen hingga dapat dilihat dalam tabel 4.2. sedangkan untuk berat jenis yang digunakan adalah sebesar $2400 \mathrm{~kg} / \mathrm{m}^{3}$. Untuk kuat tekan dari slab beton PC yang digunakan adalah sebesar f'c $=32,85 \mathrm{Mpa}$ dengan kuat tarik sebesar 3,28 Mpa.

Tabel 1

Input Material[5]

\begin{tabular}{|c|c|c|c|}
\hline No. & Type & $\begin{array}{c}\text { Poisson's } \\
\text { Ratio }\end{array}$ & $\begin{array}{c}\text { Strength } \\
\text { R,MPa }\end{array}$ \\
\hline 1 & PCC Surface & 0,15 & 4,41 \\
\hline 2 & Base & 0,2 & 0 \\
\hline 3 & Subbase & 0,35 & 0 \\
\hline 4 & Subgrade & 0,4 & 0 \\
\hline
\end{tabular}

1. Keadaan I Single Wheel (Interior Loading)

Keadaan I yaitu beban diterapkan pada bagian tengah suatu pelat yang terletak cukup jauh dari tepi atau sambungan. 
Tabel 2

Validasi Tegangan Analisis Program Bantu Elemen Hingga dengan Westergaard Single Wheel (Interior Loading)

\begin{tabular}{|c|c|c|c|}
\hline \multirow[b]{2}{*}{ No } & \multirow[b]{2}{*}{ Tebal Pelat $(\mathrm{mm})$} & \multicolumn{2}{|c|}{ Interior Loading Single Wheel } \\
\hline & & $\begin{array}{l}\text { Tegangan Tarik Maksimum } \\
\text { Program Bantu Elemen Hingga }\end{array}$ & $\begin{array}{l}\text { Tegangan Tarik Maksimum } \\
\text { Westegaard (Mpa) }\end{array}$ \\
\hline 1 & 310 & 3 & 2.8925 \\
\hline 2 & 330 & 2,8991 & 2,5992 \\
\hline 3 & 350 & 2,5688 & 2,3475 \\
\hline 4 & 370 & 2,2890 & 2,1299 \\
\hline 5 & 390 & 2,0508 & 1,9405 \\
\hline 6 & 410 & 1,8462 & 1,7747 \\
\hline$\frac{0}{7}$ & 430 & $\frac{1,0402}{1,6692}$ & $\frac{1,1,477}{1,6287}$ \\
\hline 8 & 450 & 1,5151 & 1,4995 \\
\hline 9 & 470 & 1,3801 & 1,3847 \\
\hline 10 & 490 & 1,2615 & 1,2822 \\
\hline 11 & 510 & 1,1566 & 1,1904 \\
\hline 12 & 530 & 1,0634 & 1,1078 \\
\hline 13 & 550 & 0,9804 & 1,0333 \\
\hline 14 & 570 & 0.9061 & 0.9658 \\
\hline 15 & 590 & 0,8394 & 0,9045 \\
\hline
\end{tabular}

2. Keadaan II Single Wheel (Edge Loading)

Beban diterapkan di dekat tepi pelat atau sambungan yang tidak mempunyai kemampuan untuk menyalurkan beban

Tabel 3

Validasi Tegangan Analisis Program Bantu Elemen Hingga dengan Westergaard Single Wheel

\begin{tabular}{|c|c|c|c|}
\hline \multirow[b]{2}{*}{ No } & \multirow[b]{2}{*}{ Tebal Pelat $(\mathrm{mm})$} & \multicolumn{2}{|c|}{ Edge Loading Single Wheel } \\
\hline & & $\begin{array}{l}\text { Tegangan Tarik Makssimum } \\
\text { Program Bantu Elemen Hingga } \\
\text { Mpa) }\end{array}$ & \begin{tabular}{|c|} 
Tegangan Tarik Maksimum \\
Westegaard (Mpa)
\end{tabular} \\
\hline 1 & 310 & 5,9334 & 5,2344 \\
\hline 2 & 330 & 5,2435 & 4,7436 \\
\hline 3 & 350 & 4,6668 & 4,3214 \\
\hline 4 & 370 & 4,1816 & 3,9554 \\
\hline 5 & 390 & 3,7661 & 3,6359 \\
\hline 6 & 410 & 3,4094 & 3,3552 \\
\hline 7 & 430 & 3,0997 & 3,1070 \\
\hline 8 & 450 & 2,8296 & 2,8865 \\
\hline 9 & 470 & 2,5928 & 2,6896 \\
\hline 10 & 490 & 2,3832 & 2,5130 \\
\hline 11 & 510 & 2,1973 & 2,3539 \\
\hline 12 & 530 & 2,0317 & 2,2101 \\
\hline 13 & 550 & 1,8833 & 2,0795 \\
\hline 14 & 570 & 1,7500 & 1,9607 \\
\hline 15 & 590 & 1,6294 & 1,8521 \\
\hline
\end{tabular}

3. Keadaan III Single Wheel (Corner Loading)

Beban diterapkan di ujung pelat. Pada contoh dibawah dihitung tegangan tarik pada dasar pelat

Tabel 4

Validasi Tegangan Analisis Program Bantu Elemen Hingga dengan Westergaard Single Wheel (Corner Loading)

\begin{tabular}{|c|c|c|c|}
\hline \multirow[b]{2}{*}{ No } & \multirow[b]{2}{*}{ Tebal Pelat $(\mathrm{mm})$} & \multicolumn{2}{|c|}{ Corner Loading Single Wheel } \\
\hline & & $\begin{array}{l}\text { Tegangan Tarik Makssimum } \\
\text { Program Bantu Elemen Hingga } \\
\text { (Mpa) }\end{array}$ & \begin{tabular}{|c}
$\begin{array}{c}\text { Tegangan Tarik Maksimum } \\
\text { Westegaard (Mpa) }\end{array}$ \\
\end{tabular} \\
\hline 1 & 310 & 4,6163 & 3,5917 \\
\hline 2 & 330 & 4,0121 & 3,2537 \\
\hline 3 & 350 & 3,5088 & 2,9609 \\
\hline 4 & 370 & 3,0865 & 2,059 \\
\hline 5 & 390 & 2,7277 & 2,4825 \\
\hline 6 & 410 & 2,4218 & 2,2856 \\
\hline 7 & 430 & 2,1591 & 2,1113 \\
\hline 8 & 450 & $\frac{2,9321}{1,932}$ & 1,9563 \\
\hline 9 & 470 & 1,7350 & 1,8179 \\
\hline 10 & 490 & 1,5631 & 1,6937 \\
\hline 11 & 510 & 1,4125 & 1,5819 \\
\hline 12 & 530 & 1,2800 & 1,4809 \\
\hline 13 & 550 & 1,1631 & 1,3893 \\
\hline 14 & 570 & 1,0595 & 1,3061 \\
\hline 15 & 590 & 0,9674 & 1,2301 \\
\hline
\end{tabular}

4. Keadaan I Dual Wheel (Interior Loading)

Pada keadaan I beban dua roda diterapkan pada bagian tengah suatu pelat yang terletak cukup jauh dari tepi atau sambungan.
Tabel 5

Validasi Tegangan Analisis Program Bantu Elemen Hingga dengan Westergaard Dual Wheel

\begin{tabular}{|c|c|c|c|}
\hline \multirow[b]{2}{*}{ No } & \multirow[b]{2}{*}{ Tebal Pelat $(\mathrm{mm})$} & \multicolumn{2}{|c|}{ Interior Loading Dual Wheel } \\
\hline & & $\begin{array}{l}\text { Tegangan Tarik Maksimum } \\
\text { Program Bantu Elemen Hingga } \\
\text { (Mpa) }\end{array}$ & $\begin{array}{l}\text { Tegangan Tarik Maksimum } \\
\text { Westegaard (Mpa) }\end{array}$ \\
\hline 1 & 310 & 3,5117 & 2,3187 \\
\hline 2 & 330 & 3,1043 & 2,1526 \\
\hline 3 & 350 & 2,7647 & 2,0027 \\
\hline 4 & 370 & 2,4786 & 1,8673 \\
\hline 5 & 390 & 2,2355 & 1,7448 \\
\hline 6 & 410 & 2,0270 & $\frac{1,1,4339}{1,639}$ \\
\hline 7 & 430 & 1,8470 & 1,5332 \\
\hline 8 & 450 & 1,6903 & 1,4416 \\
\hline 9 & 470 & 1,5532 & 1,3606 \\
\hline 10 & 490 & 1,4323 & 1,2904 \\
\hline 11 & 510 & 1,3254 & 1,2252 \\
\hline 12 & 530 & 1,2302 & 1,1648 \\
\hline 13 & 550 & 1,1451 & 1,1085 \\
\hline 14 & 570 & 1,0686 & 1,0562 \\
\hline 15 & 590 & 0,9996 & 1,0074 \\
\hline
\end{tabular}

5. Keadaan II Dual Wheel (Edge Loading)

Beban dua roda diterapkan di dekat tepi pelat atau sambungan yang tidak mempunyai kemampuan untuk menyalurkan beban.

Tabel 6

Validasi Tegangan Analisis Program Bantu Elemen Hingga dengan Westergaard Dual Wheel

\begin{tabular}{|c|c|c|c|}
\multicolumn{5}{c|}{ (Edge Loading) } \\
\cline { 3 - 4 } No & \multirow{3}{*}{ Tebal Pelat (mm) } & \multicolumn{2}{|c|}{ Edge Loading Dual Wheel } \\
\cline { 3 - 4 } & & $\begin{array}{c}\text { Tegangan Tarik Maksimum } \\
\text { Program Bantu Elemen Hingga } \\
\text { (Mpa) }\end{array}$ & $\begin{array}{c}\text { Tegangan Tarik Maksimum } \\
\text { Westegaard (Mpa) }\end{array}$ \\
\hline 1 & 310 & 5,8416 & 3,6244 \\
\hline 2 & 330 & 5,1612 & 3,3927 \\
\hline 3 & 350 & 4,939 & 3,1815 \\
\hline 4 & 370 & 4,1160 & 2,9889 \\
\hline 5 & 390 & 3,7095 & 2,8129 \\
\hline 6 & 410 & 3,3607 & 2,6520 \\
\hline 7 & 430 & 3,593 & 2,5045 \\
\hline 8 & 450 & 2,7970 & 2,3692 \\
\hline 9 & 470 & 2,5672 & 2,2447 \\
\hline 10 & 490 & 2,3648 & 2,1300 \\
\hline 11 & 510 & 2,1855 & 2,0241 \\
\hline 12 & 530 & 2,0260 & 1,9261 \\
\hline 13 & 550 & 1,8833 & 1,8353 \\
\hline 14 & 570 & 1,7552 & 1,7510 \\
\hline 15 & 590 & 1,6398 & 1,6726 \\
\hline
\end{tabular}

D. Analisis Sensitivitas

Pada tahap analisis ini dicoba permodelan slab beton yang bertujuan untuk mengetahui sensivitas penggunakan program bantu elemen hingga terhadap beberapa keadaan

1. Analisis Sensitivitas Terhadap Perletakan

Pada tahap ini dilakukan analisis tegangan untuk semua variasi letak roda pesawat keadaan I, keadaan II dan keadaan III dibuat dengan asumsi perletakan yang sama. Asumsi perletakan untuk keadaan II dan keadaan III dibuat sama dengan keadaan I yaitu disemua sisi diasumsikan menggunakan perletakan fixed support.

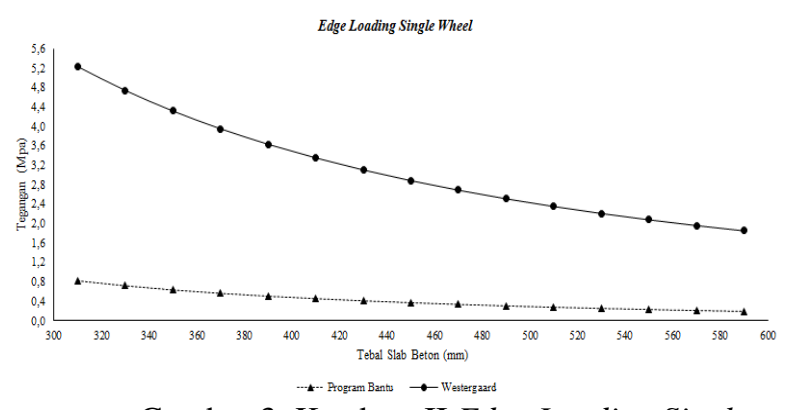

Gambar 3-Keadaan II Edge Loading Single Wheel Asumsi Fixed Suppord 


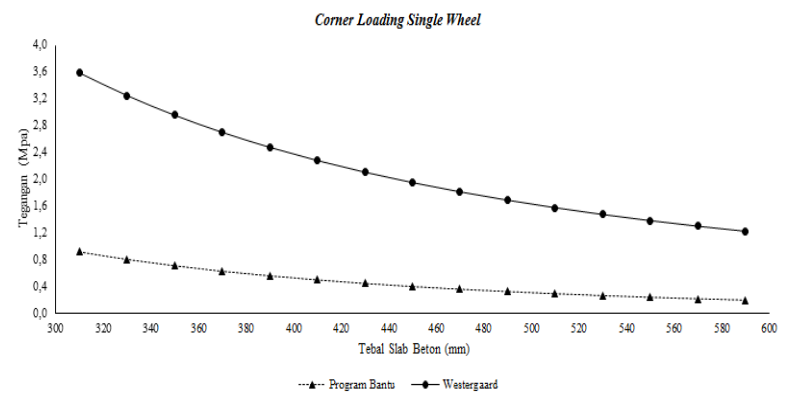

Gambar 4-Keadaan III Corner Loading Single Wheel Asumsi Fixed Suppord

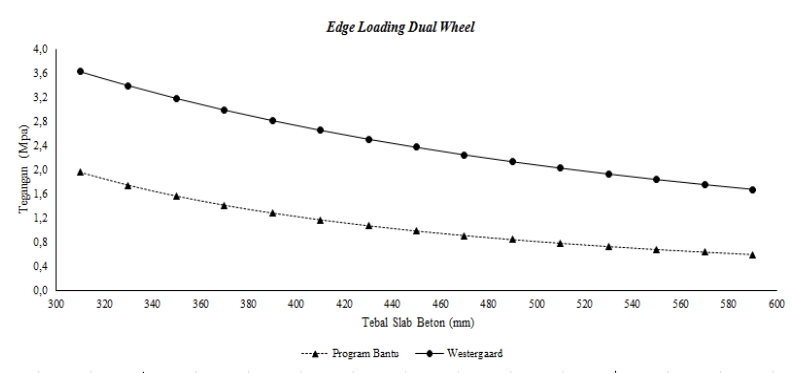

Gambar 5-Keadaan II Edge Loading Dual Wheel Asumsi Fixed Suppord

2. Analisis Sensitivitas Terhadap Perletakan Pada tahap ini melakukan analisis tegangan yang terjadi di suatu slab beton apabila letak roda pesawat berada pada diantara interior dan edge yaitu berjarak 1082,27 mm dari pinggir slab beton. Pada tahap ini roda pesawat digunakan beban roda single wheel yang kemudian hasil tegangan di tiap-tiap ketebalan akan divalidasi dengan analisis Westergaard keadaan II edge loading single wheel. Asumsi perletakan yang digunakan adalah dibuat sama dengan keadaan I yaitu disemua sisi diasumsikan menggunakan perletakan fixed support.

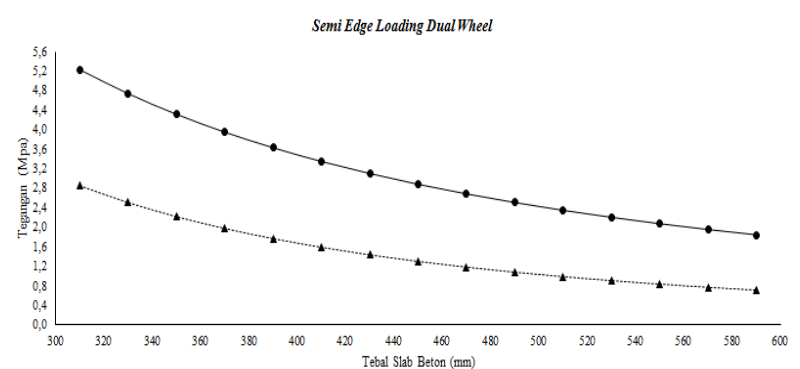

Gambar 6-Analisis Sensitivitas Terhadap Letak Roda Pesawat

E. Menentukan Tebal Slab Beton Ijin Tiap-Tiap Variasi Material Slab Beton

Variasi material slab beton yang digunakan adalah variasi campuran material beton geopolimer[4]. Beton geopolimer akan dianalisis dengan program bantu elemen hingga dengan metode yang sama seperti halnya menganalisis beton PC. Pada tahap analisis ini input material properti beton geopolimer yang digunakan adalah material beton geopolimer yang telah diuji di dalam laboraturim. Hasil dari analisis beton geopolimer ini nanti akan dibandingkan dengan hasil analisis beton PC, sehingga hasil dari perbandingan akan diperoleh material slab beton yang paling efektif. Jenisjenis material Geopolimer yang digunakan

- Beton Geopolimer 1 (GC-1,5-0,4): Beton Geopolimer 8M dengan perbandingan massa alkali aktifator $\frac{\mathrm{Na}_{2} \mathrm{SiO}_{3}}{\mathrm{NaOH}}=1.5$ dengan penambahan serat PVA sebesar $0.4 \%$

- Beton Geopolimer 2 (GC-1,5-0,6): Beton Geopolimer $8 \mathrm{M}$ dengan perbandingan massa alkali aktifator $\frac{\mathrm{Na}_{2} \mathrm{SiO}_{3}}{\mathrm{NaOH}}=1.5$ dengan penambahan serat PVA sebesar $0.6 \%$

- Beton Geopolimer 3 (GC-2,0-0,6): Beton Geopolimer 8M dengan perbandingan massa alkali aktifator $\frac{\mathrm{Na}_{2} \mathrm{SiO}_{3}}{\mathrm{NaOH}}=2.0$ dengan penambahan serat PVA sebesar $0.6 \%$

- Beton Geopolimer 4 (GC-2,5-0,4): Beton Geopolimer 8M dengan perbandingan massa alkali aktifator $\frac{\mathrm{Na}_{2} \mathrm{SiO}_{3}}{\mathrm{NaOH}}=2.5$ dengan penambahan serat PVA sebesar $0.4 \%$

- Beton Geopolimer 5 (GC-2,5-0,6): Beton Geopolimer 8M dengan perbandingan massa alkali aktifator $\frac{\mathrm{Na}_{2} \mathrm{SiO}_{3}}{\mathrm{NaOH}}=2.5$ dengan penambahan serat PVA sebesar $0.6 \%$

- Beton Geopolimer 6 (GC-2,5-0,8): Beton Geopolimer 8M dengan perbandingan massa alkali aktifator $\frac{\mathrm{Na}_{2} \mathrm{SiO}_{3}}{\mathrm{NaOH}}=2.5$ dengan penambahan serat PVA sebesar $0.8 \%$

Adapun rekapan karakteristik material dari tiap-tiap jenis beton geopolimer yang digunakan sebagai permodelan dalam program bantu elemen hingga yaitu:

Tabel 7

Input Karakteristik Jenis Material Beton Geopolimer [6]

\begin{tabular}{|c|c|c|c|c|c|}
\hline \multirow{2}{*}{ No } & \multirow{2}{*}{$\begin{array}{c}\text { Jenis } \\
\text { Beton }\end{array}$} & $\begin{array}{c}\text { Berat } \\
\text { Jenis }\end{array}$ & $\begin{array}{c}\text { Kuat } \\
\text { Tekan }\end{array}$ & $\begin{array}{c}\text { Modulus } \\
\text { Elastisitas }\end{array}$ & \multirow{2}{*}{$\begin{array}{c}\text { Poisson } \\
\text { Ratio }\end{array}$} \\
\cline { 3 - 5 } & & $\left(\mathrm{kg} / \mathrm{m}^{3}\right)$ & $\mathrm{Mpa})$ & \multirow{2}{*}{$(\mathrm{Mpa})$} & \\
\hline 1 & $\mathrm{GC}-1,5-0,4$ & 2427,12 & 61,6 & 20910 & 0,381 \\
\hline 2 & $\mathrm{GC}-1,5-0,6$ & 2443,25 & 57,6 & 24470 & 0,054 \\
\hline 3 & $\mathrm{GC}-2,0-0,6$ & 2438,996 & 69 & 15060 & 0,292 \\
\hline 4 & $\mathrm{GC}-2,5-0,4$ & 2455,516 & 51,4 & 24010 & 0,006 \\
\hline 5 & $\mathrm{GC}-2,5-0,6$ & 2462,445 & 54 & 7980 & 0,165 \\
\hline 6 & $\mathrm{GC}-2,5-0,8$ & 2475,11 & 56,9 & 13000 & 0,383 \\
\hline
\end{tabular}

Untuk menentukan tebal slab beton yang diijinkan digunakan nilai tegangan pada slab beton. Nilai tegangan tarik maksimum yang diijinkan untuk semua jenis material disamakan dengan nilai kuat tarik beton Portland Cement (PC) yaitu diambil sebesar 10\% dari kuat tekan beton maksimum yaitu 3,28 Mpa.

a. Slab beton PC

Jadi tebal slab beton minimum yang dapat digunakan untuk beton PC sebesar $425 \mathrm{~mm}$. TEGANGAN BETON PC

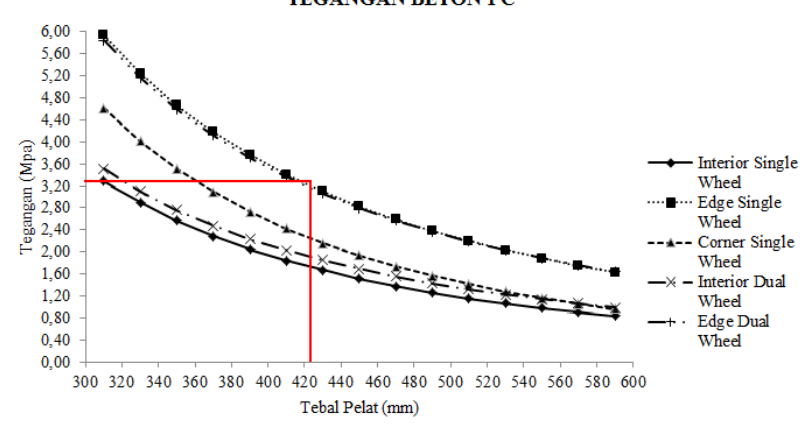

Gambar 7-Tebal Slab Minimum Beton PC

b. Slab Beton Geopolimer GC-1,5-0,4

Jadi tebal slab beton minimum yang dapat digunakan untuk beton geopolimer GC-1,5-0,4 sebesar $445 \mathrm{~mm}$. 


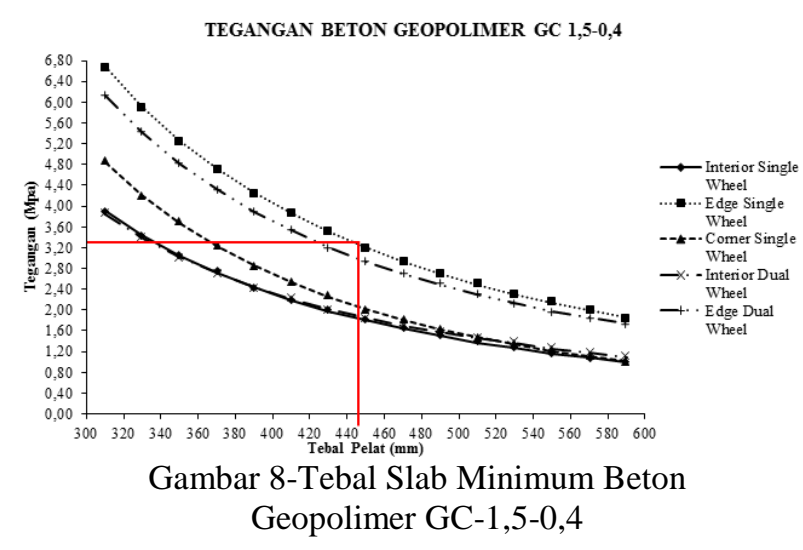

c. Slab Beton Geopolimer GC-1,5-0,6

Jadi tebal slab beton minimum yang dapat digunakan untuk beton geopolimer GC-1,5-0,6 sebesar $418 \mathrm{~mm}$.

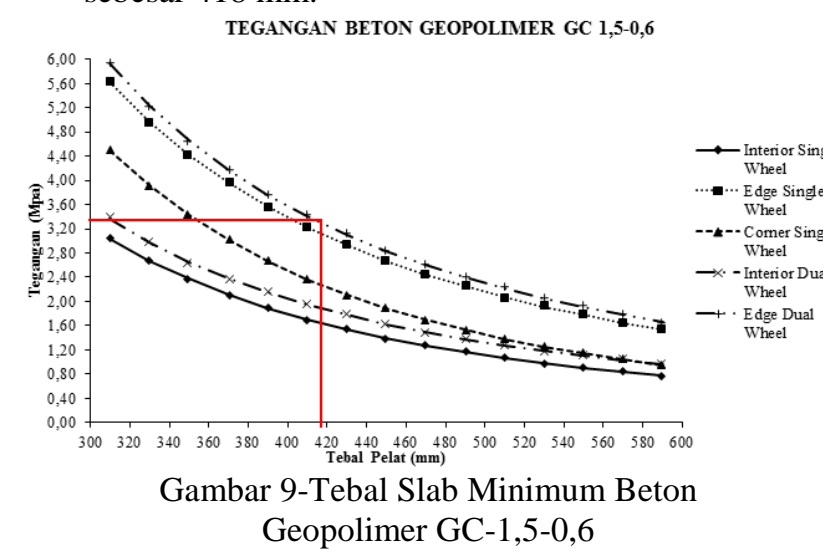

d. Slab Beton Geopolimer GC-2,0-0,6

Jadi tebal slab beton minimum yang dapat digunakan untuk beton geopolimer GC-2,0-0,6 sebesar $430 \mathrm{~mm}$.

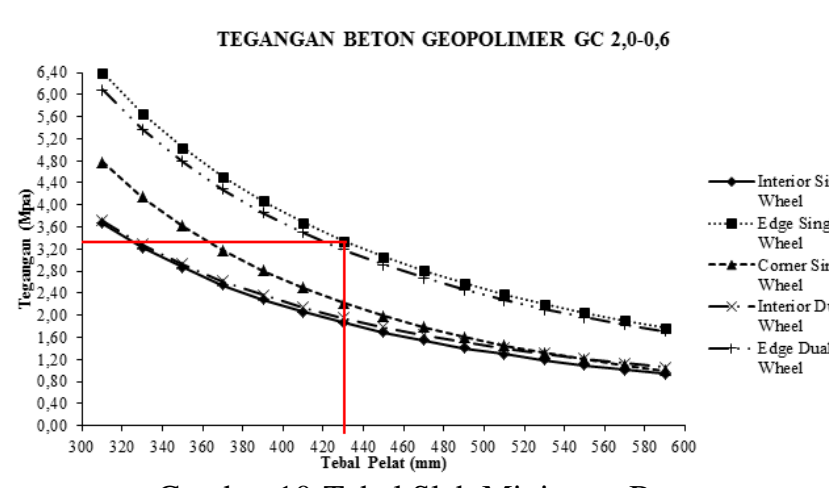

Gambar 10-Tebal Slab Minimum Beton Geopolimer GC-2,0-0,6

e. Slab Beton Geopolimer GC-2,5-0,4

Jadi tebal slab beton minimum yang dapat digunakan untuk beton geopolimer GC-2,5-0,4 sebesar $415 \mathrm{~mm}$.

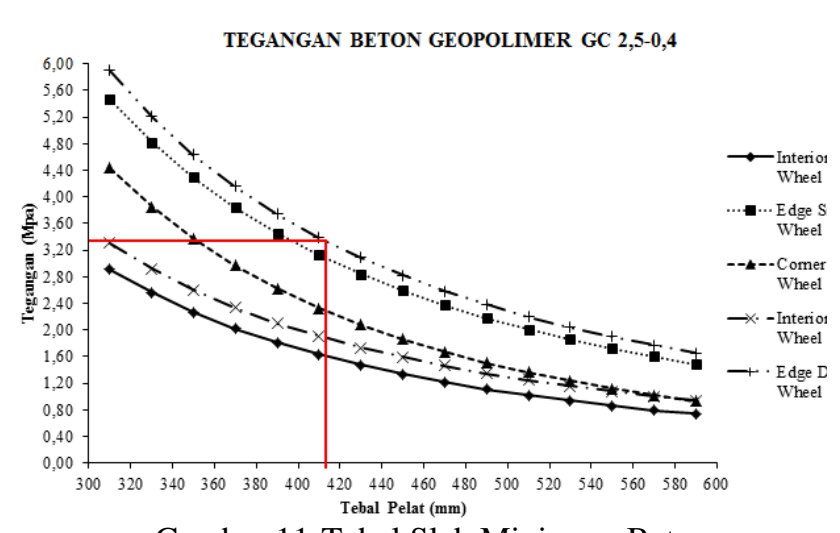

Gambar 11-Tebal Slab Minimum Beton Geopolimer GC-2,5-0,4 f. Slab Beton Geopolimer GC-2,5-0,6

Jadi tebal slab beton minimum yang dapat digunakan untuk beton geopolimer GC-2,5-0,6 sebesar $416 \mathrm{~mm}$.

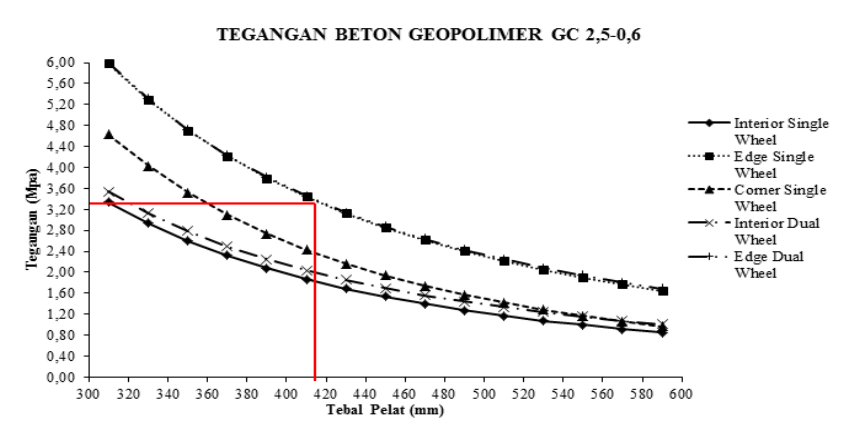

Gambar 12-Tebal Slab Minimum Beton Geopolimer GC-2,5-0,6

g. Slab Beton Geopolimer GC-2,5-0,8

Jadi tebal slab beton minimum yang dapat digunakan untuk beton geopolimer GC-2,5-0,8 sebesar $440 \mathrm{~mm}$.

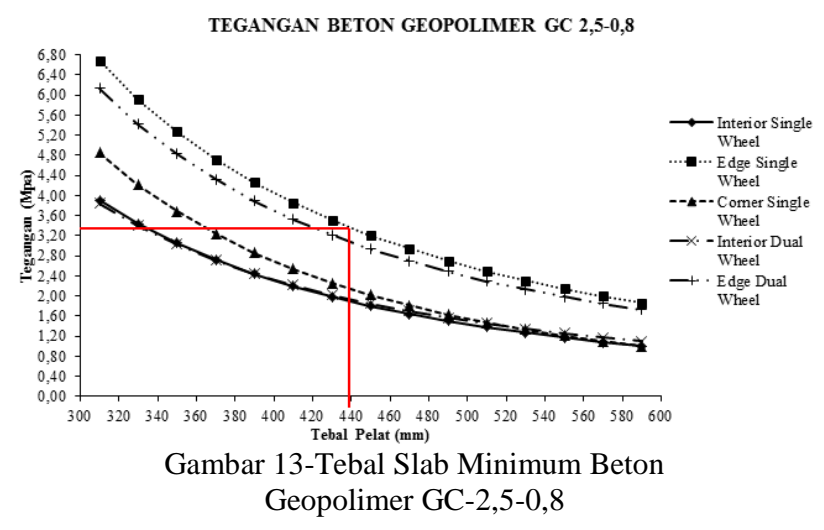

F. Faktor Kelelahan (Fatigue)

Berdasarkan hasil perhitungan faktor kelelahan(Fatigue) dengan metode PCA beton dengan material beton PC juanda masih dapat melayani pergerakan pesawat dalam kurun waktu lebih dari 20 tahun dikarenakan nilai total kerusakan pada material slab beton apron hanya sebesar 83,56\% sedangkan material slab beton dikatakan kritis apabila total kerusakan sudah mencapai $100 \%$. Rekapitulasi perhitungan dapat dilihat dalam tabel 6 dibawah ini.

Tabel 8

Rekapitulasi Faktor Kelelahan Beton

\begin{tabular}{|c|c|c|c|c|c|c|c|c|c|c|}
\hline No & $\begin{array}{c}\text { Type } \\
\text { Pesarat }\end{array}$ & $\begin{array}{c}\text { Total } \\
\text { Annual } \\
\text { depatures }\end{array}$ & $\begin{array}{c}\text { Weight } \\
\text { on main } \\
\text { gear }\end{array}$ & $\begin{array}{c}\text { Tegangan } \\
\text { lentur }\end{array}$ & $M R_{90}$ & $\begin{array}{c}\text { Stress } \\
\text { Ratio }\end{array}$ & $\begin{array}{c}\text { Repetisi } \\
\text { Beban } \\
\text { Dijijnkan }\end{array}$ & $\begin{array}{c}\text { Fratigue } \\
\text { Repetion }\end{array}$ & $\begin{array}{c}\text { Kapasitas } \\
\text { Stukkural }\end{array}$ \\
\hline 1 & B732 & 3916 & 108100 & 270 & 640,05 & 0,422 & $\infty$ & $\infty$ & $\infty$ & $\infty$ \\
\hline 2 & B733 & 1609 & 127120 & 290 & 640,05 & 0,453 & $\infty$ & $\infty$ & $\infty$ & $\infty$ \\
\hline 3 & B734 & 13716 & 141319,5 & 310 & 640,05 & 0,484 & 1805912 & 0,0057 & 78,130 & 0,087 \\
\hline 4 & B735 & 3503 & 123414 & 290 & 640,05 & 0,453 & $\infty$ & $\infty$ & $\infty$ & $\infty$ \\
\hline 5 & B738 & 9942 & 163519,2 & 360 & 640,05 & 0,562 & 100000 & 0,0746 & 741,325 & 14,827 \\
\hline 6 & B739 & 21392 & 163519,2 & 360 & 640,05 & 0,562 & 100000 & 0,1604 & 3432,132 & 68,643 \\
\hline 7 & B7444 & 32 & 810348 & 380 & 640,05 & 0,009 & 23885 & 0,0010 & 0,032 & 0,003 \\
\hline 8 & B76 & 559 & 324024 & 325 & 640,05 & 0,508 & 533692 & 0,0008 & 0,439 & 0,002 \\
\hline & TOTAL & 54669 & & & & & & & & 83,560 \\
\hline
\end{tabular}

\section{A. Kesimpulan}

\section{KESIMPULAN DAN SARAN}

1. Desain tebal pelat beton pada struktur perkerasan apron yang dilakukan dengan metode FAA dengan software FAARFIELD menghasilkan nilai sebesar $442,5 \mathrm{~mm}$. Tebal perkerasan yang dihasilkan oleh FAARFIELD lebih kecil dari kondisi real dari bandara Juanda yang saat ini sebesar $450 \mathrm{~mm}$. 
2. Permodelan slab beton untuk apron pada program bantu elemen hingga yaitu digunakan slab beton berbentuk kubus dengan ukuran 5000 x $5000 \mathrm{~mm}$, dengan ketebalan bervariasi mulai dari 310-590 mm dengan kelipatan $20 \mathrm{~mm}$. Ukuran meshing sebesar $50 \mathrm{~mm}$ dengan bentuk kotak. Untuk pembebanan pada analisis ini digunakan pembebanan roda pesawat B737-400.

3. Dalam menganalisis tegangan yang terjadi pada serat bawah slab beton apron menggunakan program bantu elemen hingga yang telah diverifikasi dengan analisis Westergaard, variasi letak pembebanan roda sangat berpengaruh pada distribusi tegangan tarik maksimum. Nilai tegangan tarik maksimum terjadi pada keaadan edge loading. Dalam hasil analisis sensitivitas menggunakan program bantu elemen hingga yang diverifikasi dengan analisis Westergaard nilai tegangan slab beton pada serat bawah hanya berlaku pada kondisi Interior loading. Nilai tegangan pada hasil analisis sensitivitas tidak bisa diverifikasi dengan Westergaard jika kondisi pembebanan terletak pada edge dan corner. Selain itu dalam permodelan slab beton nilai tegangan pada serat bawah slab beton sangat sensitif terhadap perletakan, karakteristik material seperti Modulus Elastisitas dan Poisson ratio. Berdasarkan hasil analisis sensitivitas terhadap letak pembebanan, permodelan slab beton akan valid jika nilai tegangan dengan asumsi pembebanan terjadi hanya pada Interior Loading dikarenakan pada analisis Westergaard tidak mendefinisikan letak roda yang dimaksud pada keadaan corner loading dan edge loading.

4. Variasi material yang digunakan dalam slab beton apron sangat berpengaruh pada ketebalan slab beton yang digunakan. Berdasarkan hasil analisis menggunakan program bantu program bantu elemen hingga tebal slab beton dengan material beton PC tebal slab beton minimum yang dapat digunakan sebesar $415 \mathrm{~mm}$. Untuk jenis dari seluruh material beton geopolimer tebal slab beton paling minimum yang dapat digunakan yaitu sebesar $415 \mathrm{~mm}$ dari beton geopolimer jenis 4 (GC-2,5-0,4).

5. Berdasarkan hasil perhitungan faktor kelelahan(Fatigue) dengan metode PCA beton dengan material beton PC juanda masih dapat melayani pergerakan pesawat dalam kurun waktu lebih dari 20tahun dikarenakan nilai total kerusakan pada material slab beton apron hanya sebesar $83,56 \%$ sedangkan material slab beton dikatakan kritis apabila total kerusakan sudah mencapai $100 \%$.

\section{B. Saran}

Dalam melakukan permodelan slab beton menggunakan program bantu elemen hingga perlu dilakukuan analisis lebih lanjut mengenai asumsi perletakan dalam permodelan slab beton. Dalam melakukakan permodelan penentuan jenis meshing sangat berpengaruh dalam menentukan nilai tegangan suatu slab beton.

Menindaklanjuti analisis sensivitas pada tugas akhir ini dalam menganalisis tegangan slab beton terhadap variasi letak roda pesawat edge loading dan corner loading perlu dicari letak yang sesuai dengan yang didefinisikan dalam analisis Westergaard. Sehingga nilai tegangan yang dihasilkan dengan program bantu elemen hingga akan valid dengan analisis Westergaard.

\section{DAFTAR PUSTAKA}

[1] Huang Y. H., 2004., Pavement Analysis and Design. New Jersey.

[2] Navneet G., 2009., - Concrete Airfield Pavement Design - Using FAARFIELD for Rigid Overlays, Concrete Airport Pavement Workshop Atlanta, Georgia.

[3] David R. B., 2012., FAARFIELD 1.3 Software Overview, Panama,.

[4] Ekaputri., 2013., Triwulan., Sodium sebagai Aktivator Fly Ash, Trass da Lumpur Sidoarjo dalam Beton Geopolimer, Bandung,.

[5] Redy T., 2014., Perbandingan Metode Perencanaan Perkerasan Kaku pada Apron Dengan Metode FAA, PCA dan LCN dari Segi Biaya Dukung, Surabaya,.

[6] Novema D.S., 2016., Pengaruh Serat PolyVinyl Alcohol (PVA) pada Karakteristik Beton Geopolimer, Surabaya,. 